\title{
Pendidikan Dan Pendampingan Terhadap Anak Sekolah Minggu Untuk Memaknai Tujuan Dari Pak Yakni Yesus Kristus Sebagai Tuhan
}

\author{
Jeni Tandi Limbong \\ Institut Agama Kristen Negeri Toraja \\ @gmail: Jenitandilimbong@gmail.com
}

\begin{abstract}
:
The purpose of raising this paper is so that there is a good understanding of the importance of mentoring and education for children through Sunday school education institutions organized by the church so that Sunday school children get attention and education and deepening about Jesus Christ as God in Christian religious education, school children. sunday know or interpret their spiritual correctly. In addition, there is also an understanding of the importance of Sunday school services to become a plague in reaching people for Christ. The method used is literature or literature method with a qualitative approach. as for reading sources, namely a collection of journals and books and the internet web. The theory is based on excerpts from journals, books and web sites.
\end{abstract}

Keywords: education, mentoring, Sunday school, children, teachers, parents
Abstrak: 
Adapun tujuan mengangkat tulisan ini adalah supaya ada pemahaman yang baik akan pentingnya pendampingan dan pendidikan bagi anak melalui lembaga pendidikan sekolah minggu yang di selenggarakan oleh gereja agar anak sekolah Minggu mendapat perhatian dan pendidikan serta pendalaman tentang Yesus Kristus sebagai Tuhan dalam pendidikan Agama Kristen, anak sekolah minggu tahu atau memaknai spiritual mereka dengan benar. Selain itu juga adanya pemahaman mengenai pentingnya pelayanan sekolah minggu untuk menjadi wabah dalam menjangkau orang-orang bagi kristus. Adapun metode yang digunakan adalah metode literature atau pustaka dengan pendekatan kualitatif . adapun sumbersumber bacaan yaitu kumpulan jurnal-jurnal dan buku dan web internet. Teori yang ada berdasarkan kutipan dari jurnal, buku dan web situs internet.

Kata Kunci: pendidikan, pendampingan, sekolah minggu, anak, Guru, orang tua.

\section{Pendahuluan (Cambria, 12pt, bold)}

Mengapa saya mengangkat judul penelitian tentang pendidikan dan pendampingan terhadap anak Sekolah Minggu Gereja Toraja di Jemaat Batulelleng untuk memaknai PAK yakni Yesus Kristus sebagai Tuhan, karena saya berfikir bahwa pentingnya memberikan pendidikan serta pendampingan bagi anak Sekolah Minggu mengenai bagaimana pemahaman Yesus Kristus sebagai Tuhan dalam Pendidikan Agama Kristen. Guru dan orang tua adalah dapat mengambil peran penting dalam pendidikan serta pendampingan anak untuk memperkenalkan nilanilai kekristenan pada anak serta mendewasakan perserta didik melalui pendidikan yang berisi ajaran kekristenan yang menekankan tiga komponen yakni aspek kognitif, afektif dan psikomotorik.

Dari pendampingan yang dilakukan oleh guru serta orang tua maka akan memudakan anak memperdalam kecerdasan spiritual dimana kecerdasan spiritual merupakan kecerdasan yang tertinggi yang perluh untuk di miliki oleh seseorang untuk memahami keberadaannya yang dapat dilihat dalam bagaimana seseorang dalam hubungannya dengan Tuhan.

Adapun peranan pendampingan guru dalam penumbuhan karakter Kristen pada anak-anak yaitu guru harus memberi diri membimbing anak pada usia dini dalam pembelajaran karakter kristen dimana karakter Karakter Kristen yang 
dimaksud adalah sama atau tidak ada bedanya dengan tindakan moral, dan hanya ada satu yang membedakan tindakan moral dengan karakter atau nilai Kristiani yaitu pada tindakan moral hanya terbatas pada aturan baik buruknya sedangkang karakter atau nilai kristiani lebih pada keserupaan dengan Kristus. Nilai Kristen yang diperoleh dari anugrah Allah yang diberikan kepada manusia. Dalam hal ini peranan guru dalam tahapan perkembangan anak dengan demikian setiap pembelajaran diberikan kepada ana sesuai dengan tahapan anak-anak. Dan guru serta orang tua harus membimbing anak-anak serta guru dan orang tua haru memiliki keyakinan bahwa karaktter ana-anak akan senantiasa bertumbuh dalam proses pimpinan roh kudus. ${ }^{1}$

Dari pandangan diatas maka saya juga melihat bahwa anak sekolah Minggu pun perluh pendampingan dari guru sekolah minggu yang bekerja sama dengan orang tua dalam memperkenalkan ajaran ke Kristenan kepada anak-anak. Bukan hanya mengajarkan nilai-nilai ke Kristenan kepada anak tetapi juga meninggalkan jejak keteladanan mengenai bagaimana karakter Kristus kepada anak.

\section{TUJUAN DAN MANFAAT}

Adapun tujuan dan maamfaat dari tulisan saya mengenai pendidikan dan pendampingan terhadap anak sekolah minggu untuk memaknai tujuan dari pak yakni Yesus Kristus sebagai Tuhan sebagai berikut:

TUJUAN

a. agar anak sekolah Minggu mendapat perhatian dan pendidikan serta pendalaman tentang Yesus Kristus sebagai Tuhan dalam pendidikan Agama Kristen.

b. Agar anak sekolah minggu tahu atau memaknai spiritual mereka dengan benar.

\section{MANFAAT}

a. Dengan pendampingan serta perhatian dan pendidikan serta pendalaman tentang Yesus Kristus sebagai Tuhan dalam pendidikan Agama Kristen. Orang tua guru dapat mempersiapkan anak Sekolah minggu menjadi kader siap utus.

\footnotetext{
${ }^{1}$ https://scholar.google.co.id/scholar?hl=id\&as_sdt=0\%2C5\&q=pemahaman+yesus+kristus+pada+anak\&btnG=\#d= gs_qabs\&u=\%23p\%3Dg6pETe3y-gUJ
} 


\section{METODE PENELITIAN}

Metode penelitian menggunakan metode pustaka atau literature dengan mengambil sumber-sumber dari jurnal, buku maupun web lainya. Serta mengunakan pendekatan kuantitatif.

\section{Pembahasan (Cambria, 12pt, bold)}

\section{Pemberitaan injil}

pendampingan pada sekolah minggu untu memperkenalkan Yesus kristus sebagai Tuhan maka perluh adanya pendampingan dari orang tua serta Guru dengan penginjilan. Beberapa orang Kristen mengajukan pertanyaan tentang bagaimana dengan agama diluar Kristus apakah akan diselamatkan? Dan bagai mana jika hidup mereka lebih baik dari orang Kristen? Dari pertanyaan- pertanyaan ini muncul dari orang-orang yang belum memahami bagaimana keslamatan dalam Yesus Kristus. Maka dari itu sangat penting pendampingan bagi Sekolah Minggu untuk memahami bagaimana keselamatan dari Yesus Kristus. Dan sangat penting untuk Sekolah Minggu mendapat pengenalan tentang siapa Kristus ? dan siapa Tuhan?

Bagaimana kita memeperkenalkan Yesus Kristus sebagai Tuhan kepada ana sekolah minggu? Kita dapat melakukan penginjilan sederhana dan masuk akal bagi anak-anak agar mereka juga dapat memahami Injil yang adalah kabar baik bagi setiap manusia. Dimana jika di beritakan maka akan memberikan upah bagi si pemberitanya dan dan memunculkan reaksi reaksi dan tindakan bagi pendengarannya yaitu ucapan terimakasih sebagai wujud kurban bagi Allah.. ${ }^{2}$ Disini kita dapat mengajar Sekolah Minggu untu bersyukur karene memahami serta mengenal Yesus Kristus sebagai Tuhan dan sumber keselamatan.

\section{Misi Penginjilan Kristen pada Sekolah Minggu}

Sekolah minggu merupakan Generasi penerus bangsa yang harus dibentuk sebagai kader siap utus yang bertanggung jawab. David Wood menjelaskan tentang segalah sesuatu yang menceritakan tentang Tuhan. Segalah sesuatu penyebab yang

\footnotetext{
2 David Eko Setiawan, "Dampak Injil Bagi Transformasi Spiritual Dan Social".jurnal teologi dan pendidikan Kristen Konstektual.vol.2.no1,juni 2019, 89-93.hal 1-11
} 
logis atau msuk akal dapat diceitakan dan bukan merupakan sesuatu yang megadah-ada atau sebuah cerita yang fiktif. Adapun sarana yang digunakan oleh David Wood adalah sebuah apologet yang secara aktif dan terus menerus mengosumsikan pemikiran ${ }^{3}$ jelas untuk penerapan yang dilakukan kepada Sekolah Minggu tidak sama dengan apa yang dilakukan oleh David Wood, namun kita bisa mengugunakan metode yang sama dengan pendekatan atau media yang berbeda namun memiliki tujuan yang sama. Adapun yang bisa kita terapkan bagi Anak sekolah minggu yaitu membuat desai cerita pengenalan Yesus Kristus secara menarik dan mudah dipahami dan memiliki dasar yang kuat dalam Alkitab.

Adapun metode lain yang bisa kita rekomendasikan pada Sekolah minggu adalah dengan menyajikan konten kreatif yang di persiapkan dengan data-data yang kuat untuk menjawab kebenan Kristus bagi Sekolah Minggu. Seperti menyajikan drama kelahiran, pelayanan, dan penderitaan Yesus Kristus. ${ }^{4}$

\section{Pembinaan Anak Bagi Warga Gereja}

Pendidikan bagi anak adalah tugas yang sangat penting bagi warga Gereja, dimana didalam gerja anak-anak harus dibimbing dengan baik sebab pendidikan anak dapat di ibaratka sebagai penyiapan generasi siap utus bagi Gereja, dan oleh karena itu perluh rasa tanggung jawab besar dalam mengambil pelayanan pada anak secara khusus di Gereja pelayanan Sekolah Minggu. Dan yang berperan penting dalam pendampingan anak selain guru disekolah danorang tua adalah guru sekolah minggu. Untuk mewujudkan pendidikan dalam gereja yang berkualitas, khususnya pada sekolah minggu maka dibutukan guru-guru sekolah minggu yang terdidik dan terlatih dan guru-guru yang memiliki rasa tanggung jawab besar dan mau memberi diri untuk mengajar sekolah minggu. Dengan tenaga guru sekolah minggu yang berkualitas maka maka akan membawa dampak positif dalam pelayanan anak khususnya anak sekolah minggu. ${ }^{5}$

\section{Pembinaan Pembinaan Moral Pada Anak Sekolah Minggu}

Pembinaan-pembinaan yang dilakukan gereja melalu sekolah minggu merupakan salah satu bentuk tanggung jawab sebagai warga Negara, dalam hal ini

\footnotetext{
${ }^{3}$ Acts17Apologitics,"science"

${ }^{4}$ Daniel Fajar Panuntun, "Misi Apologetika Kristen Online di Era Dirupsi”. Jurnal Apostolos, vol 2 No 1,2019. Hal.113

${ }^{5}$ Riniwati, "pembinaan Guru Sekolah Minggu Untuk Mengajarkan Konsep Keselamatan Kepada Anak".jurnal teologi injili dan pembinaan warga jemaat, volume 4, nomor 2, juli 2020 .hal.194
} 
berupa bentuk keterlibatan warga negara sebagai tanggung jawab melihat berbagai permasalahan yang muncul dalam masyarakat khususnya pada kenakalan anak. Dengan ada perhatian terhadap pembinaan sekolah minggu setidaknya dapat meberikan jalan keluar bagi permasalan tersebut dengan membekali anak dengan ilmu moral serta memperkuat iman anak. Pembinaan terhadap anak merupakan salah satubentu usaha mentalitas agar agar menjadi warga Negara yang baik dan menghidari masalah-masalah yang kerap sering terjadi dalam masyarakat. Keterlibatan gereja merupakan sikap warga Negara karena di dalamnya ada ikatan social. Keterlibatan gereja merupakan suatu aspek penting karena memainkan perang yang penting dalam mepromosikan kesejateraan anak melalui kegiatan sekolah minggu. ${ }^{6}$

\section{Pendidikan Sekolah Minggu}

Gereja sebagai pusat pendidikan Kristen bertanggung jawab melaksanakan pendidikan Kristen seutuhnyabaik terhadap orang-orang dewasa termasuk tehadap anak-anak. Sekolah minggu merupakan salah satu layanan pendidikan Kristen yang dilaksanakan oleh gereja dalam rangka pembinaan kerohanian anak agar dapat mengenal Yesus Kristus sebagai Tuhan dan Juruslamatnya. ${ }^{7}$ Sekolah minggu juga menjadi wadah pelayanan yang penting guna menjangkau orang-orang dan kemudian mengembangkan mereka seperti Dia (Yesus Kristus) agar dalam diri anak sekolah minggu terpancar citra diri Yesus Kristus dan meneladaninya. ${ }^{8}$

\section{Sekolah Minggu Sebagai Amanat}

Keberhasila sekola minggu dalam membentuk anak-anak yang telah dipercayakan Tuhan kepada orang tua dan gereja akan ditentukan oleh sebagaimana mereka memiliki pengalaman belajar yang berarti selama mereka mengikuti kegiatan sekolah minggu. ${ }^{9}$ Keberadaan sekolah minggu sangat berpengaruh sebagai wadah pelayanan bagi Kristusdimana gereja merupakanrumah bagi anak sekolah minggu dalam dalam pembinaan anaka sekolah

\footnotetext{
${ }^{6}$ Ludovikus Bomans Wadu,dkk, "Pembinaan Moral ANAK-Anak Melalui Sekolah Minggu di Gereja Santo Andreas Tidar, malang".volume 3 No 2 2019, hal.7

7 Daniel Fajar Panuntun,dkk, “Model Ibadah Sekolah Minggu Kreatif-Interaktif Bagi Generasi Alfa Di Gereja Toraja"

${ }^{8}$ Harry M. Piland, Perkembangan Gereja Dan Penginjilan Melalui Sekolah Minggu(Bandung:Lembaga Literatur Baptis,1984), 7

${ }^{9}$ Yudha Nata Saputra, "Penilaian Berbasis Test Di Sekolah Minggu", jurnal teologi injili dan pembinaan warga jemaat, volume 4,Nomor 2, juli 2020,hal.11
} 
mingguyang bertujuan memperkenalkan anak-anak sekolah minggu kepada Yesus Kristus sebagai Tuhan dan Juruslamat. ${ }^{10}$

\section{Kesimpulan dan Saran}

Sekolah minggu sebagai lembaga pendidikan yang diadakan oleh gereja sebagai wadah pelayanan bagi anak-anak dengan maksud sebagai upaya menjangkau orang-orang bagi Kristus. Di lembaga pendidikan Gereja sangat penting bagi pelayanan anak karena di sekolah minggu anak- anak mendapat pendampingan dan pengenalan akan kebenaran dan keselamatan yang dapat diteriman dalam Tuhan melalui Yesus Kristus yang adalah Tuhan dan Juruselamat.

Saya sadar bahwa dalam penulisan saya ini sangat banyak kekurangan dan kesalahan baik dari penulisan kata dan pengutipan saya mohon maaf atas kesalahan dalam penulisan dan saya mohon kritik dan saran yang membangun kiranya dalam penulisan selanjutnya bisa menjadi pembelajaran dan perbaikan dalam menulis. Harapan saya semoga tulisan ini dapat bermamfaat saya dan pembaca.

\section{Referensi}

Acts17Apologitics,"science"

Ambo' Pasongli', Lushiana ,OSF Preprints,2020

Bomans Wadu, Ludovikus dkk, "Pembinaan Moral ANAK-Anak Melalui Sekolah Minggu di Gereja Santo Andreas Tidar, malang”.volume 3 No 22019.

Eko Setiawan, David, “Dampak Injil Bagi Transformasi Spiritual Dan Social”.jurnal teologi dan pendidikan Kristen Konstektual.vol.2.no1,juni 2019.

Fajar Panuntun, Daniel dkk, "Model Ibadah Sekolah Minggu Kreatif-Interaktif Bagi Generasi Alfa Di Gereja Toraja"

Fajar Panuntun, Daniel, "Misi Apologetika Kristen Online di Era Dirupsi". Jurnal Apostolos, vol 2 No 1,2019.

https://scholar.google.co.id/scholar?hl=id\&as_sdt=0\%2C5\&q=pemahaman+yesus+kristus +pada+anak\&btnG=\#d=gs_qabs\&u=\%23p\%3Dg6pETe3y-gUJ

M. Piland, Harry, Perkembangan Gereja Dan Penginjilan Melalui Sekolah Minggu(Bandung:Lembaga Literatur Baptis,1984)

Nata Saputra, Yudha ,"Penilaian Berbasis Test Di Sekolah Minggu", jurnal teologi injili dan pembinaan warga jemaat, volume 4,Nomor 2, juli 2020

${ }^{10}$ Lushiana Ambo' Pasongli',OSF Preprints,2020,hal.9 
Riniwati, "pembinaan Guru Sekolah Minggu Untuk Mengajarkan Konsep Keselamatan Kepada Anak".jurnal teologi injili dan pembinaan warga jemaat, volume 4, nomor 2, juli 2020 